IZA DP No. 8174

Coworkers, Networks, and Job Search Outcomes

Perihan Ozge Saygin

Andrea Weber

Michèle A. Weynandt

May 2014 


\title{
Coworkers, Networks, and Job Search Outcomes
}

\author{
Perihan Ozge Saygin \\ University of Mannheim
}

\author{
Andrea Weber \\ University of Mannheim, CEPR and IZA \\ Michèle A. Weynandt \\ University of Mannheim, CDSE
}

Discussion Paper No. 8174

May 2014

IZA
P.O. Box 7240
53072 Bonn
Germany

Phone: +49-228-3894-0

Fax: +49-228-3894-180

E-mail: iza@iza.org

\begin{abstract}
Any opinions expressed here are those of the author(s) and not those of IZA. Research published in this series may include views on policy, but the institute itself takes no institutional policy positions. The IZA research network is committed to the IZA Guiding Principles of Research Integrity.

The Institute for the Study of Labor (IZA) in Bonn is a local and virtual international research center and a place of communication between science, politics and business. IZA is an independent nonprofit organization supported by Deutsche Post Foundation. The center is associated with the University of Bonn and offers a stimulating research environment through its international network, workshops and conferences, data service, project support, research visits and doctoral program. IZA engages in (i) original and internationally competitive research in all fields of labor economics, (ii) development of policy concepts, and (iii) dissemination of research results and concepts to the interested public.
\end{abstract}

IZA Discussion Papers often represent preliminary work and are circulated to encourage discussion. Citation of such a paper should account for its provisional character. A revised version may be available directly from the author. 


\section{ABSTRACT}

\section{Coworkers, Networks, and Job Search Outcomes}

Social networks are an important channel of information transmission in the labor market. This paper studies the mechanisms by which social networks have an impact on labor market outcomes of displaced workers. We base our analysis on administrative records for the universe of private sector employment in Austria where we define work-related networks formed by past coworkers. To distinguish between mechanisms of information transmission, we adopt two different network perspectives. From the job-seeker's perspective we analyze how network characteristics affect job finding rates and wages in the new jobs. Then we switch to the perspective of the hiring firm and analyze which types of displaced workers get hired by firms that are connected to a closing firm via past coworker links. Our results indicate that employment status and the firm types of former coworkers are crucial for the job finding success of their displaced contacts. Moreover, $21 \%$ of displaced workers find a new job in a firm that is connected to their former workplace. Among all workers that were displaced from the same closing firm those with a direct link to a former coworker are twice as likely to be hired by the connected firm than workers without a link. These results highlight the role of work related networks in the transmission of job information and strongly suggest that job referrals are an important mechanism.

JEL Classification: J63, J64, M51

Keywords: $\quad$ social networks, job displacement, plant closure, referral hiring

Corresponding author:

Andrea Weber

University of Mannheim

L7, 3-5, Room 420

68131 Mannheim

Germany

E-mail: a.weber@uni-mannheim.de

\footnotetext{
* We are grateful to David Card for helpful discussions and suggestions. We thank participants at the EALE conference 2013 and seminar participants at Mannheim, Berkeley, Linz, Uppsala, Freiburg, Essen, Berlin, Bonn, Amsterdam and Bergen for their comments. The authors also thank the Center for Labor Economics at the Economics Department at the University of California, Berkeley where the paper was partly written for its hospitality and generous support. This project received funding from the Austrian Science Fund (NRN Labor Economics and the Welfare State).
} 


\section{Introduction}

The labor market is characterized by an enormous degree of heterogeneity between workers and jobs, which makes the matching process between both sides of the market highly complex. It has long been recognized that personal relations, informal contacts, and social networks play a big role in overcoming the informational difficulties (Granovetter, 1974; Rees, 1966). Survey evidence across countries indicates that $30-50 \%$ of workers have found their jobs with the help of friends, family members, or coworkers. Employers, on the other side of the market, tend to rely heavily on employee referrals and word-of-mouth techniques in recruitment. ${ }^{1}$ A central point of interest is therefore how social networks operate in the labor market and how they influence outcomes.

The literature has discussed two main mechanisms of information transmission in labor market networks. The first mechanism investigates the exchange of information about job opportunities among social contacts. Following this idea, Calvo-Armengol and Jackson (2004) design a model of social networks, where employed network members pass on job related information to their unemployed contacts. The empirical literature testing this mechanism, typically examines how the properties of social networks affect job search outcomes. ${ }^{2}$ The second mechanism is motivated by the employers' hiring strategies where social networks generate job referrals for specific vacancies for example if a worker recommends an unemployed contact to their employer for a potential hire. Models of referral hiring are based on the intuition that in a market with adverse selection employers face an informational advantages by hiring referred applicants (Dustmann et al., 2012; Montgomery, 1991; Simon and Warner, 1992). In this spirit, the empirical literature tests whether hiring probabilities, productivity, or profits differ between referral and non-referral workers.

In this paper we bring together the different perspectives on information transmission mechanisms, acknowledging that in the job matching process both workers and employers make use of social networks. This approach allows us to assess the relative importance of job related information and job referrals on job search outcomes. Our setting focuses on workers who are displaced by closing firms and consequently forced to search for new jobs. We define their social networks by the past coworkers with whom they shared a workplace over the last five years be-

\footnotetext{
${ }^{1}$ For surveys of the recent literature see Ioannides and Loury (2004) and Topa (2011). (Pellizzari, 2010) presents a comparison of job search channels across European countries. Information from large companies with employee referral programs Brown et al. (2012); Burks et al. (2014) up to 50\% of non-entry level jobs filled by referrals. Recent survey evidence from Austria shows that $72 \%$ of unemployed job seekers search for new jobs via friends and relatives, and a third of them report finding a new job via social contacts (Eppl et al., 2014).

${ }^{2}$ For references see Section 2
} 
fore displacement. The setup is implemented in the Austrian Social Security Database (ASSD) which covers the universe of private sector workers over a period of 30 years and results in a large sample and very detailed networks.

Our analysis then proceeds along three main steps. We start with the job seekers' perspective and investigate how the properties of a displaced worker's social network affects their job search outcomes. If information about job opportunities is passed on from employed to unemployed network members, the share of employed network members should have an impact on job finding rates. In the second step, we investigate whether the type of firms in which former coworkers are employed matters for job search outcomes. We focus on the firms' industries and demand side factors such as the wage level and employment growth of the firms. The idea is that if demand side factors are relevant for search outcomes they most likely operate through the job referral channel, as a contact in a expanding firm will be especially effective if this firm offers a job to the displaced job seeker.

To confirm this intuition further, we switch to the perspective of the hiring firms in the third step of our analysis. The concept of former coworker networks allows us to construct a network between firms by linking each closing firm to a set of connected firms in which the former coworkers of displaced workers are employed. Based on this firm network we examine the hiring probabilities of displaced workers. In particular, we compare hiring probabilities of displaced workers with and without a direct link to a former coworker in the connected firm. Although we lack information on actual employee referrals, we take the existence of an individual's former coworker in a connected firm as a proxy for a referral. The results of the hiring analysis will thus give us further indication on the importance of referral hirings.

A key concern in the empirical analysis of social networks is non-random selection into networks. If individuals select into networks based on shared unobserved characteristics, a clear identification strategy is necessary to distinguish causal network effects from spurious correlation of the outcomes among network members. We define social networks by past coworkers, which has the advantage that the networks are not formed with the primary objective of generating information about job opportunities. Nevertheless, coworkers networks are determined by shared employment histories and are thus not generated randomly with respect to labor market outcomes. Our strategy is to isolate demand side variation in network characteristics from the employment history components, for which we can control with a detailed set of variables. Even if former coworkers are similar to the displaced worker, the type of firms where they are em- 
ployed should be driven by random variation. In addition, we restrict the analysis to variation at the closing firm level. The counterfactual experiment is thus determined by displaced workers from the same closing firm who have different network characteristics. In the analysis of hiring probabilities, we compare displaced workers from the same closing firm where one of them holds a link to a former coworker in the connected firm and the other one does not.

Our analysis leads to the following main findings. First, we confirm previous findings that the share of employed network members increases job finding rates. In the Austrian application, an increase of the share of employed network members by one standard deviation increases the job finding hazard by $4 \%$, or the probability of finding a new job within three months by 1.3 percentage points. Second, the type of firms in which network members are employed matters for job search outcomes. The share of network members employed in expanding firms increases the job finding rate, while the share of network members employed in high wage firms leads to higher wages in the new jobs. Third, connected firms are important for the employment prospects of displaced workers as $21 \%$ of them find a new job in a connected firm. Fourth, we find strong evidence in favor of the referral hiring channel. Displaced workers with a link to a former coworker in a connected firm are more than twice as likely to be hired by that firm. Fifth, there is some evidence of heterogeneity of network effects across groups of workers, which is confirmed by both the the job seekers analysis and the hiring analysis. Especially older workers, white collar workers, and job seekers with Austrian nationality benefit from former coworker networks.

Besides the literature on job search networks, which we will review in more detail in the next section, our paper is also related to the literature on job displacement. This literature documents strong and persistent adverse effects in terms of employment stability and earnings from job displacement (Fink et al., 2014; Jacobson et al., 1993; Von Wachter and Davis, 2011; Von Wachter et al., 2011). It will therefore be interesting to shed some light on the extent to which these losses can be mitigated by social network effects.

The structure of the paper is as follows. In the next section we discuss the theoretical background by presenting the main models of information exchange and referral hiring in the literature. This section also gives an overview of the empirical literature testing these models. Section 3 describes the data, introduces our network concept, and presents a detailed descriptive analysis of coworker and firm networks. We present the main empirical analysis and results in Section 4 , and the final section concludes. 


\section{Theoretical Background and Empirical Literature}

The job searchers perspective is adopted in the model of information transmission in social networks by Calvo-Armengol and Jackson (2004). In this framework a social network consists of a group employed and unemployed workers where network members randomly receive information about job opportunities. Unemployed workers keep this information for themselves and take the job, while employed members pass on the information to one of their unemployed contacts. This mechanism ensures that unemployed network members have two sources of job information, the information they receive themselves and information transferred via their employed contacts. In a network with many employed members unemployed workers will find jobs more quickly than in networks with mostly unemployed members where each worker has to rely on the information they receive themselves. Thus the model predicts that the share of employed network members has a positive impact on job finding rates of job seekers. The information traded in the network is general information about job opportunities. For the prediction of the model to hold, the type of firms where the employed contacts work does not necessarily have an additional effect on job finding success of jobseekers.

Models incorporating the firms' interests are based on a setting where employers face uncertainty about the productivity of applicants when they take the recruitment decision and a workers productivity is only revealed over time (Jovanovic, 1979). Employee referrals help employers recruit, because they provide additional information about the applicant which would otherwise not be available. Simon and Warner (1992) and more recently Dustmann et al. (2012) develop models, where employers can hire either through referrals or on the open market, and derive predictions about starting wages, wage growth, and job turnover which can be tested empirically. Montgomery (1991) takes a slightly different approach based on the assumption of homophily, stating that workers are more likely to hold ties to individuals who are similar to themselves. Once the type of a worker is revealed, the employer will thus only hire referrals from highly productive workers which are more likely to be highly productive types themselves. The type of information that is shared among network members in the referral models is very specific. Employed contacts encourage their job seeking network members to apply for a vacancy at their firms. The predictions from models of referral hiring imply that the type of firms where employed networkers are working should be reflected in the job search outcomes. In addition, we should see job seeking network members who join their employed contacts in the same firms.

A third alternative mechanism by which social contacts affect search outcomes is mostly 
discussed in the literature on peer effects. Instead of exchanging job related information, social networks might directly affect workers' preferences for work or leisure (Bandiera et al., 2009; Marmaros and Sacerdote, 2002; Mas and Moretti, 2009). In a network of mostly employed members an unemployed worker, who wants to be similar to her peers, will be subject to social pressure to search harder for a job. If this were the mechanism at play, we would expect to find strong impacts from the employment status of network members on job search outcomes, while the types of network members' firms or the availability of vacancies at the firms would not be relevant.

The popularity of informal job search methods among job seekers, and the large share of jobs that are generated by personal contacts has been documented in numerous studies; Ioannides and Loury (2004) and Topa (2011) provide excellent surveys of this literature. More recently, two studies have tested the predictions from the model by Calvo-Armengol and Jackson (2004) in networks based on former coworkers and a setting that is very similar to ours. Cingano and Rosolia (2012) and Glitz (2013) show for Italy and Germany that the share of employed coworkers has a positive impact on job finding rates of displaced workers. Glitz (2013) applies an instrumental variable strategy to account for network endogeneity. Exploiting variation in the employment rate of former coworkers from mass-layoffs, he finds even stronger network effects.

The widespread use of referral hiring techniques by employers is well documented on the basis of survey evidence of employers hiring strategies; see e.g. Marsden (2001), Holzer (1987), and Topa (2011) for an overview. In addition, studies based on evidence from personnel records of large firms show that referred applicants are more likely to be invited for job interviews and subsequently also more likely to get hired (Brown et al., 2012; Castilla, 2005). Burks et al. (2014) use very detailed data from nine large firms in different industries with application records and productivity measures, which allow them to compare the predictions from theoretical models of employer hiring. They find that no single model is fully confirmed by the data.

Furthermore, several studies provide indirect evidence on the importance of the referral hiring mechanism. These are based on different definitions of social networks. In the context of the literature on neighborhood effects, Bayer et al. (2008), and Hellerstein et al. (2011), and Hawranek and Schanne (2014) find that individuals living in the same residential location are also more likely to work in the same firms than individuals living in neighboring locations. Defining networks along ethnic minority group dimensions, Dustmann et al. (2012) show that firms with high share or migrant workers are more likely to hire additional workers from the same 
ethnicity. In the same context Aslund et al. (2014) and Giuliano et al. (2009) find that immigrant managers are substantially more likely to hire immigrants than natives. Using family based networks, Kramarz and Nordström Skans (2013) find that high school graduates more likely to find their first jobs in a parent's firm. Most similar to our analysis is the study by Hensvik and Nordström Skans (2013) who define work-related networks by former co-workers. They show that firms are more likely to hire a former-coworker of one of their incumbent employees than a random applicant from the open market. This effect is even stronger for high ability incumbent employees, which confirms the prediction by Montgomery (1991).

\section{Data and Network Definitions}

Our empirical analysis is based on the Austrian Social Security Database (ASSD), which covers the universe of private sector workers in Austria over the years 1972-2012 (Zweimüller et al., 2009). The data provide detailed daily information on employment, unemployment, and other states relevant for social security such as sickness, retirement, or maternity leave. Earnings paid by each employer are recorded at an annual level. The matched employer-employee structure of the ASSD is defined by employer identifiers, which are linked to individual employment spells. To measure workforce characteristics at the firm level, we organize the data in a quarterly panel, collapsing it along employer identifiers. Firm exit dates are then defined as the last quarter date in which a firm employs at least one worker. We use a worker-flow approach to distinguish firm closures from other exit events such as mergers or institutional changes in the employer identifier. This approach is explained in detail in Fink et al. (2010). ${ }^{3}$

Our sample of displaced workers consists of individuals displaced by firm closures over the years 1980 - 2007. We make four restrictions to this sample. First, we only consider blue collar or white collar workers, who are still employed in the quarter of firm exit. In the following we will refer to this quarter alternatively as the firm closure quarter or the displacement quarter. Second, we restrict the sample to workers with at least one year of tenure at the closing firm. Third, we focus on workers who are between 20 and 55 years of age at displacement. Fourth, we only consider firm closures that involve at least 2 displaced individuals. The resulting sample includes 151,432 workers displaced from 27,960 closing firms, which means that on average we observe 5.4 workers displaced by the same closing firm. ${ }^{4}$

\footnotetext{
${ }^{3}$ The main definition is that a closure is restricted to the exit of an employer identifier where less than $50 \%$ of the last year's workforce jointly move to the same new employer identifier. Because this approach is not meaningful for very small firms, we restrict closures to firms with at least 5 employees in the last year.

${ }^{4}$ Because our sample is based on universe of Austrian private sector workers, and because of the long time
} 


\section{Displaced Workers and Coworker Networks}

For each displaced worker the social network is defined as the set of all individuals who shared a workplace with her over the last five years before the displacement quarter. Thereby we require that the employment spells of the contacts overlap for at least 30 days. We further exclude links with former coworkers that were established in very large firms with more than 3000 employees. This restriction facilitates the computational tractability but more importantly it restricts the size of the networks and excludes very large networks, which encompass limited information about interpersonal information flows. Finally, we also exclude co-displaced workers form the network, who were displaced by the same firm closure event. These workers will form the comparison group at the closing firm level.

Table 1 presents summary statistics of individual and network characteristics of our sample of displaced workers. The average worker's age at displacement is 36.8 , a share of $41 \%$ are females, $92 \%$ are of Austrian nationality, and $53 \%$ hold a blue collar contract at displacement. The average displaced worker's tenure - 4.9 years - is slightly below the length of the time window over which the network is formed, but the distribution of job tenure is right skewed and the median is at 2.9 years. Typically, displaced workers experience interruptions in their labor market careers over the five year window. On average a displaced worker experienced one job change over the last five years, worked for 4.3 out of the 5 years, and spent 50 days in unemployment. Firms in the Austrian labor market are generally small, which is also reflected in size of firms where displaced workers were employed during the 5 year window. The average firm size over the last 19 quarters prior to displacement is 50, and the median firm size is about 20. Closing firms in the displacement quarter are even smaller and a displaced worker has 13 co-displaced workers on average and 7 at the median.

The employment history characteristics of displaced workers indicate that the size of coworker networks is typically determined by rapid employment turnover of both the displaced workers and their former coworkers, rather than by stable employment spells in large firms. The average network size of about 160 former coworkers is thus almost three times as large as the average firm size over the past 5 years, the median network size is smaller with 44 former coworkers. ${ }^{5}$

frame, our sample of closing firms and displaced individuals is larger than the samples used in previous studies. Glitz (2013) uses establishment closures in the Hamburg, Cologne, Frankfurt and Munich metropolitan areas in the years 1995 and 1996. This leaves him with 10,916 displaced male workers from 1,814 establishments. Cingano and Rosolia (2012) focus on two Italian provinces (Treviso and Vicenza) and observe 9,121 displaced and re-employed individuals from 1,195 firm closures in the manufacturing sector over the years 1980 to 1994 . The displaced workers of Cingano and Rosolia (2012) have to be employed in the closing firm in the last month of activity.

${ }^{5}$ Note that the co-displaced workers, whom we exclude from the network are in general only a small fraction 
In general, there is a lot of diversity within the coworker networks: on average about $40 \%$ of network members are female, a share of $62 \%$ are blue collar workers, and a share of $92 \%$ have Austrian nationality. If we compare displaced workers to the members of their networks, we see that about $68 \%$ of them have the same gender as the displaced worker, which indicates a slight selection into networks by gender, $86 \%$ of network members share the same nationality with the displaced worker, $69 \%$ hold the same job type, and $28 \%$ are in the same age group, where we split displaced workers into four age groups of about equal size.

Next, we turn to the employment characteristics of network members and focus on the jobs which the network members hold in the displacement quarter. At the time of firm closure on average $56 \%$ of the network members hold a job. ${ }^{6}$ If we compare the industry of the closing firm with the industries of the firms where network members are employed, we find that only $19 \%$ of the contacts' industries overlap at the 2 digit level. ${ }^{7}$ We construct two further measures, which provide information about employment dynamics and wage levels of the firms where network members are employed. First, we are interested whether network members hold jobs in expanding firms, approximated by the firms' employment growth over the displacement quarter. We find that on average $24 \%$ of the network members are employed in "net hiring firms", defined as firms with an absolute increase in the number of blue and white collar workers in the displacement quarter. Second, we look at the share of network members who are employed in "high wage" firms. To approximate the firm wage level, we generate quartile groups of average male wages. According to this measure, we see that a relatively high share of $30 \%$ of network members are employed in firms that pay above median wages. ${ }^{8}$

Figure 1 shows an example of the structure of the coworker networks. To construct this graph, we selected a one percent random subsample of 85 workers who were displaced in the year 2000. The displaced worker is shown at the center of each coworker network and the edges represent links to the former coworkers. We see that the sizes of the networks vary a lot, the largest includes about 2000 contacts and the smallest has only a single contact. Some displaced workers have networks that overlap, while other networks are isolated. This is potentially due to the random draw of displaced workers from the full population. In general, networks of two

of all former coworkers. For the average displaced worker the group of co-displaced workers amounts to roughly $20 \%$ of all former coworkers over the past 5 years. The median is lower with $14 \%$.

${ }^{6}$ The share of employed coworkers is similar to the one reported by Glitz (2013) for Germany, but lower than the corresponding number in Cingano and Rosolia (2012).

${ }^{7}$ To classify industries we use a two digit NACE classification, which covers about 60 different industries.

${ }^{8}$ We define quartiles of the average male wages in firms with at least 3 male employees in a certain quarter. Firms with fewer employees are then categorized in the quartile 1 group. We focus on male wages to avoid problems with part time workers, who are predominantly female. 
individuals who are displaced from the same firm will overlap to a certain extent. However, unless their employment careers are identical during the last 5 years, the networks will only partly overlap. Colors in the graph represent the gender of displaced workers and network members. The figure suggests that there is some gender segregation in networks, as some of them predominantly consist of men or women.

\section{Closing Firms and Firm Networks}

At the firm level we construct networks by linking each closing firm to a network of connected firms, which builds on the individual level former coworker networks. In particular, the set of connected firms is defined by the firms in which the former coworkers of displaced individuals are employed at the closure date. One way to think of the set of connected firms is as a proxy of the local labor market which offers new job opportunities to the displaced worker. Based on this definition our set of 27,960 closing firms is connected to 352,995 firms, which span a large fraction of the overall market.

Table 2 presents the main characteristics of closing firms and their networks of connected firms. As mentioned above, closing firms in the ASSD are fairly small. Among all firms who layoff at least 2 workers in the closing quarter, the average number of displaced workers is 5.4 and the median is 4 workers. During their lifetime, these firms were not large either. In the quarter with its maximum size, the average closing firm employed 24 workers, and the median firm employed 13. On average closing firms stayed in the market for about 10 years. Closing firms also pay low wages, in the quarter of firm closure the wages in closing firms are below the median firm level wages. ${ }^{9} 30 \%$ percent of closing firms operated in Vienna and they are fairly equally distributed across industries. ${ }^{10}$

Next, we turn to the firm networks of closing firms. On average a closing firm has former coworker links to 173 connected firms; the median number of connected firms is 55 . The average size of connected firms is much larger than the size of closing firms and the average wage level in connected firms is above the median. Interestingly, firms networks are not segregated by industries, but the typical firm network spans a variety of industries. On average a closing firm is linked to 27.7 connected firms in the same industry, the median is 7 . This means that on average only about a third of the links from the closing to connected firms is are among firms in the same two digit level industry. At the regional level, firm networks are slightly more

\footnotetext{
${ }^{9}$ Note that this is partly due to the small size of closing firms. According to our definition of wage "quartiles" firms with less than three male employees in one quarter are coded in the bottom wage category.

${ }^{10}$ Due to the seasonal nature of the construction and tourism sectors in Austria, we will check whether our results are robust to excluding these industries. See Appendix Table A.3.
} 
segregated with about $55 \%$ of linked firms operating in the same region as the closing firm. ${ }^{11}$

At the level of a pair of closing and connected firm there are on average two displaced workers with links to former coworkers who are employed in the connected firm at the displacement quarter.

Figure 2 shows an example of a firm network. The figure is based on is a random subsample of 60 firms closing down in the year 2000. At the center of each network we see the closing firms and edges represent links to connected firms. The color of the links represent industry connections: a red edge means that the pair of closing and connected firm are in the same industry, while a yellow edge represents different industries. The nodes are colored by the wage quartiles of the firms, with a lighter blue color representing a lower quartile firm. The small sample indicates that closing firm are mostly low wage firms, while there are more high wage firms with darker color among the connected firms. If we compare the network structure between Figure 1 and Figure 2, it appears that multiple links from one connected firm to several closing firms are more prevalent within the firm network than in workers' networks.

\section{Job Search Outcomes}

Descriptive statistics of job search outcomes of displaced workers are shown in Table 3. About $85 \%$ of the displaced workers in our sample find a new job within one year after the displacement date. The average time to find a new job is 83 days, censored at 365 days, while the median is only 2 days. This reflects the fact that not all displaced workers are out of employment after the layoff. About $47 \%$ transit to a new job immediately after leaving the closing firm and a share of $33 \%$ of displaced workers are registered as unemployed.

To examine job search outcomes in more detail, we focus on the subset of successful job seekers who find a job within the first year after job displacement. The average time between displacement and the start of the new job is 38 days for this group, and more than half of successful searchers find a new job immediately. On average, the change in log wage between the pre- and post-displacement jobs is close to zero, but there is some variation. If we compare pre-and post-displacement industries and regions, we find that about $50 \%$ of the workers find new jobs in the same industry and $80 \%$ find a new job in the same region. We also check whether displaced workers return to a previous employer, where they had worked during the last 5 years. This happens for about $7 \%$ of the sample.

Next, we consider individual links to the connected firms within the firm network. We discuss

\footnotetext{
${ }^{11}$ This is based on there digit nuts regional classification, covering about 30 regions.
} 
the numbers for successful job searchers, but as it can be seen from Table 3 the statistics are similar for the full sample of displaced workers. On average, a displaced worker has access to a relatively large number of about 380 connected firms via all former coworkers of the group of workers displaced by the same firm closure event. To 60 out of the 380 the displaced worker is connected via a direct link to one of their own former coworkers. The share of connected firms to which the average displaced worker holds a direct link is $40 \%$ of all connected firms. Finally, we look at the job matches that form within firm networks. We see that about $25 \%$ of successful displaced workers find a new job in one of the firms that are connected to the closing firm and $19 \%$ find a new job in a connected firm to which they have a personal link. These numbers suggest that referral hirings are potentially an important channel of information transmission in the coworker networks. We will examine this channel more closely in the empirical analysis.

\section{Empirical Analysis}

The empirical analysis proceeds in two parts, which exploit the job search dimension and the hiring dimension of the coworker networks. From the job searcher's perspective, we start by investigating the effects of networks characteristics on the job finding rates and wage growth after job displacement. Our main identification strategy consists of comparing workers who were displaced from the same closing firms but have different networks. This will give us a first indication whether coworker networks have an impact on job search outcomes. The second part of our analysis aims at narrowing down the channel by which information is transmitted among network members. We will exploit the firm dimension of coworker networks and investigate the probability that a displaced worker finds a job in a firm that is connected to closing firm. Thereby we will focus on the role of the displaced worker, the connected firm, and a potential link to a former coworker in the connected firm on the magnitude of the social tie effect.

\subsection{Job Search Analysis}

The model of information transmission in social networks by Calvo-Armengol and Jackson (2004) predicts that the share of employed network members is crucial for the job-finding success of unemployed workers. To get a first impression of this connection in our sample we present weekly hazard rates into new jobs over the first year after displacement in Figure 3. We specifically focus on two subsamples of the total population: displaced workers with a share of employed former coworkers in the top quartile of the distribution, which we denote as workers with a "high network employment rate", and displaced workers with a share of employed former coworkers in 
the bottom quartile of the distribution, denoted as "low network employment rate". The figure shows declining patterns in the weekly exit hazard rates for both groups but especially during the initial weeks of job search the exit rate of individuals with a high network employment rate is clearly above the exit rate of individuals with low network employment rate. After about 5 to 6 months of job search the two lines in the graph converge and there is hardly any difference in exit hazard rates.

To see whether the graphical impression also holds after controlling for individual characteristics and closing firm effects, we estimate proportional hazard models for the risk of finding a new job in the first year after displacement. These models include unrestricted daily baseline hazards at the closing firm level, a set of individual level covariates $X$ such as age, gender, nationality, detailed labor market and earnings history characteristics, and variables that capture events during the five years of network formation such as the average firm size and number of the employer changes. The main regressors of interest are a set of network characteristics $N W$. Specifically, we model the discrete hazard function $h\left(T \mid X_{i j}, N W_{i j}\right)$ as the probability that individual $i$ displaced form firm $j$ finds a job after $T$ days, given that she has not exited to a job up to day $T-1$, as

$$
h\left(T \mid X_{i j}, N W_{i j}\right)=\lambda_{j}(T) \exp \left(\alpha X_{i j}+\beta N W_{i j}\right)
$$

where the baseline function $\lambda_{j}(T)$ specifies the closing firm specific hazard rates when all covariates are set to zero, and $\alpha$ and $\beta$ are the vectors of coefficients to be estimated. Observations with durations longer than 365 days are treated as right censored.

Table 4 presents the estimation results. Columns (1) to (5) present estimates from separate regressions including different sets of network characteristics. ${ }^{12}$ All models control for the log network size to account for network heterogeneity in terms of the number of contacts. After controlling for the average firm size and employment turnover of displaced workers during the 5 years of network formation, we find that larger networks lead to faster job take-ups. The coefficient in first specification indicates that a increase in network size by one standard deviation increases the job exit rate by about $3 \%$. After controlling for additional network characteristics the size effect drops to about half in columns (2) to (5).

In line with the graphical results from Figure 3, the share of former coworkers who are employed in the displacement quarter has a large and significant impact on the job finding rate. The magnitude of the effect in column (1) implies a one standard deviation increase in the share

\footnotetext{
${ }^{12} \mathrm{~A}$ Table with full set of covariates is available on request.
} 
of employed former coworkers increases the exit rate to jobs by about $4 \%$. This is similar in magnitude to the effect reported by Cingano and Rosolia (2012), but somewhat smaller than the IV estimates by Glitz (2013).

The remaining model specifications in Table 4 include variables representing the types of firms where former coworkers are employed. Column (2) controls for the share of former coworkers who are working in firms operating in the same industry as the closing firm. It turns out that former coworkers in same industry firms are about twice as effective as other employed coworkers for finding new jobs.

The next specification in column (3) takes demand side factors from the firms in which former coworkers are employed into account. Social contacts in expanding firms might be more helpful for displaced workers, because these firms typically have open vacancies. This intuition is confirmed by the regression coefficient. The share of former coworkers employed in net hiring firms, defined as firms that were growing in the quarter of job displacement, further increases the exit rate to new jobs. Column (4) examines if this effect also holds for the share of former coworkers who are employed in firms that are growing in two consecutive quarters to make sure that the hiring of a former coworker is not the only reason for the employment growth in these firms. As the estimated coefficient remains of the same magnitude and statistically significant, we conclude that former coworkers employed in expanding firms are potentially an important source of information about vacancies in their firms.

The final specification in column (5) examines the effect of former coworkers who are employed in firms that pay above median wages to their average male employees. Here the coefficient is small and insignificant and we cannot see an impact on the job finding rate.

We further check the robustness of our results with respect to the model specification and to the measurement of the network characteristics. Appendix Table A.1 presents results for a set of regressions that are based on linear probability models for an indicator variable equal to one if the individual is finds a new job within 3 months after displacement. The results from the linear model are in general similar to the results from the proportional hazard model. The coefficient from the specification in column (1) implies that a one standard deviation increase of the share of employed network members increases the probability of finding a job within 3 months by 1.3 percentage points from a base mean of $72 \%$. Concerning the results from the remaining specifications, we note that the effect of the share of employed network members is fully captured by the share of network members employed in the same industry and the share employed in hiring 
firms. After controlling for these two network characteristics the network employment rate has no additional effect on re-employment probabilities within the first 3 months.

Next, we estimate hazard rate models that take into account changes in the network characteristics over time. The hazard rate models models in Table 4 are based on network characteristics measured in the displacement quarter. For job seekers who are still out of work some time after displacement, however, the network characteristics at a later date may be more relevant. Appendix Table A.2 therefore presents results from hazard models that allow for time varying network characteristics in the first quarters after job displacement. Qualitatively and quantitatively these results are not different from the estimations with fixed network characteristics. This is not surprising, as we have seen in Figure 3 that the largest differences in exit rates between individuals with high and low shares of employed former coworkers appear in the first months after displacement.

\section{Wage Growth}

After having established the importance of network characteristics on the job finding rate, we investigate whether coworker networks also have an impact on the characteristics of the new jobs. We focus on the sample of successful job seekers, who find a new job in the first year after displacement and compare their pre-and post-displacement wages. Specifically, we estimate the following regression model:

$$
y_{i j}=X_{i j} \alpha+N W_{i j} \beta+\gamma_{j}+u_{i j}
$$

where $y_{i j}$ denotes the difference in log wages before and after displacement and $\gamma_{j}$ controls for closing firm fixed effects. The effects of individual and network characteristics are given by the parameters $\alpha$ and $\beta$. We estimate separate models for males and females, because monthly wages in the ASSD can only be constructed from annual earnings and we have no control over changes in working hours.

Estimation results for men, presented in Table 5, show that network characteristics have only small and mostly insignificant effects on wage growth. The only significant coefficient is on the share of former coworkers employed in high wage firms. Increasing this share by one standard deviation, raises the the average wage gain by one percentage point. This result suggests that wage gains might be due to individuals finding jobs in higher paying firms where their former coworkers are employed. 
Results for women, shown in Table 6, are quantitatively in line with the results for males. In contrast to men, women's wages also seem to benefit from former coworkers who are employed in the same industry and from former coworkers employed in expanding firms. This could indicate that women who are able to return to employment more quickly also benefit in terms of reemployment wages.

\section{Heterogeneity of Job Finding Rates}

Next, we examine whether the network effects are heterogeneous for different groups of displaced workers. In addition, we investigate whether former coworkers with similar characteristics have stronger impacts on the job finding rate. We estimate hazard rate models similar to equation (1) for several sub-populations, with controls for log network size and the share of employed network members. In particular, we divide network members into four distinct categories: employed network members of the same population group, employed network members of the opposite population group, not employed network members of the same population group, and not employed network members of the opposite population group, who form the reference group.

Estimation results by gender, occupation, and nationality are shown in Table 7 . To facilitate the comparison of the estimated effects across columns and across different groups of network members, we standardize the covariates such that the coefficient estimates correspond to the effects of a one standard deviation increase of the independent variable. The first column reports the result for female displaced workers. Females benefit from employed female or male former coworkers to a similar extent. An increase of employed former coworkers of either gender by one standard deviation increases the job finding rate by about $5-6 \%$. Even non-employed female network members are more important for job finding success of women than non-employed male network members. Males, shown in column (2), in comparison, mostly benefit from employed male former coworkers, while employed female network members are slightly less important. Non-employed contacts of either gender do not have any effect on the job finding rate of male displaced workers. If we compare network effects by occupation, in columns (3) and (4), we note that the impacts of employed former coworkers on the job finding rates of white collar workers are much stronger than fore blue collar workers. An increase of the share of employed former coworkers by one standard deviation corresponds to an shift in the hazard rate by about $8-9 \%$ for white collar workers, but only for an increase by about $2 \%$ for blue collar workers. Interestingly, white collar workers benefit from all types of employed former coworkers, white and blue collar. Non employed blue collar network members do not seem to be profitable for 
either type of job seeker. Cutting the sample by nationality reveals that job information seems to be mostly traded among Austrian workers. Job finding rates of displaced workers with Austrian nationality are more than twice as highly correlated to the share of employed Austrian former coworkers than to employed formers coworkers of other nationalities. For displaced workers with non-Austrian nationality, we do not find any significant network effects. However, this sample is rather small and heterogeneous as it includes all individuals with non-Austrian nationality.

Table 8 reports network effects on the job finding rates by age groups. Here the results also indicate some heterogeneity. Overall, the workers in the oldest and in the youngest age groups seem to be most affected by the employment rate among former coworkers, while prime age workers appear to be less reliant on their networks for finding a new job.

\subsection{Hiring Analysis}

The results so far confirm that network characteristics are strongly related to job search outcomes of displaced workers. In line with Cingano and Rosolia (2012) and Glitz (2013) we find that the share of employed former coworkers has a positive impact on job finding rates. But which is the mechanism driving these results? Our results provide suggestive evidence that job referrals might be an important channel. We find that the type of firms where former coworkers are employed matters. Especially former coworkers in expanding firms have a positive impact on job finding rates. In addition, we find wage gains in the new job for displaced workers whose former coworkers are employed in high wage firms. Arguably, the firm type should only matter for search outcomes if network information leads to jobs in these expanding or high wage firms.

The next part of the analysis examines the importance of the referral channel further. We exploit the firm dimension of the coworker network and ask the question: What is the contribution of a link to a former coworker employed at firm $l$ on the probability that the displaced individual $i$ gets hired at $l$ ? We start by specifying a the following regression model:

$$
P_{i, j, l}=\beta L_{i l}+\gamma_{j l}+\epsilon_{i l}
$$

where $P_{i, j, l}$ denotes the probability that individual $i$, displaced from firm $j$ is hired by a firm $l$ and $L_{i l}$ is an indicator equal one if the individual holds a link to a former coworker who is employed at $l$. Thus $\beta$ measures the network effect. To avoid spurious correlation in unobservable characteristics of the worker and the firm, which might occur if firm $l$ is generally more likely to hire workers of $i$ 's type, we control for fixed effects $\beta_{j l}$ at the pair level of closing and hiring firms. The counterfactual analysis identifying the network effect $\beta$ thus compares two workers 
displaced by the same closing firm $j$ where one of them holds a link with a former coworker employed in firm $l$ and the other one does not.

Variation in $L_{i l}$ that contributes to the identification of the network effect comes from variation in connections to firm $l$ among individuals displaced from the same closing firm $j$. In particular, observations involving hiring firms $l$ without former coworker ties to any of the displaced workers from $j$ do not contribute to identification. This reduces the analysis to hiring probabilities within the set of connected firms. Among the connected firms identification relies on those firms to which only a subset of displaced workers have a link. As we have seen in the summary statistics in Tables 2 and 3 there is ample variation in the fraction of displaced workers with a link to a connected firm in our data.

To make estimation of the model tractable, we apply a fixed effects transformation suggested by Kramarz and Thesmar (2013) and applied by Kramarz and Nordström Skans (2013). In particular, we collapse equation (3) at the closing - connected firm level and consider the share of linked individuals displaced from closing firm $j$, who are hired by connected firm $l, R_{j, l}^{L i n k}$, given by

$$
R_{j, l}^{L i n k}=\frac{\sum_{i} P_{i j l} * L_{i l}}{\sum_{i} L_{i l}}=\beta+\gamma_{j l}+u_{i l}^{L i n k}
$$

and the the share of non-linked individuals displaced from closing firm $j$, who are hired by connected firm $l, R_{j, l}^{\text {noLink }}$, given by

$$
R_{j, l}^{n o L i n k}=\frac{\sum_{i} P_{i j l} *\left(1-L_{i l}\right)}{\sum_{i}\left(1-L_{i l}\right)}=\gamma_{j l}+u_{i l}^{n o L i n k}
$$

The difference between these two expressions determines the coefficient of interest $\beta$ as

$$
G_{j, l}=R_{j, l}^{L i n k}-R_{j, l}^{n o L i n k}=\beta+u_{i l} .
$$

OLS estimates of equation (4) are consistent as long as $\epsilon_{i l}$ is uncorrelated with $L_{i l}$ in equation (3), which holds true if all unobserved heterogeneity is captured by the closing-connected firm fixed effect.

Estimation results are shown in Table $9 .{ }^{13}$ The first row presents the estimate of $\beta$ and its components for the full sample. The parameter on the link indicator variable is estimated with

\footnotetext{
${ }^{13}$ Standard errors are clustered at the closing firm level. Estimations are weighted by the number of links between the closing and connected firm. Unweighted results are shown in Appendix Table A.4.
} 
high precision. To interpret the magnitude of the link effect, we compare the share of linked workers who get hired $R_{j, l}^{L i n k}$ with the share of non-linked workers who get hired $R_{j, l}^{n o L i n k}$. The ratio between the two is 2.4 for the full sample, which means that workers with a direct link are more than twice as likely to be hired by the connected firm than similar workers from the same closing firm without a link.

To see whether the result for the overall sample is driven by certain subgroups, we repeat the estimation for various subsamples in the remaining columns of Table 9. Although the coefficient estimate of the link effect varies across groups, for example $\beta$ is higher in pairs of closing connected firms in the same industry, the ratio between the share hired with link and the share hired without link is roughly stable around a value of 2 . For example, both linked and non-linked individuals have a higher probability of being hired by a connected firm in the same industry. We also confirm that the link effect does not change over time, by region, and for larger closing firms which potentially have a more variation of links across connected firms.

The next part of our analysis investigates whether the hiring probabilities and link effects are heterogeneous by types of displaced workers. We extend the basic model in equation (3) to include covariates $X_{i}$ capturing individual job searcher characteristics and an interaction term between $X_{i}$ and the link indicator $L_{i l}$

$$
P_{i, j, l}=\beta^{0} L_{i l}+\beta^{x} L_{i l} X_{i}+\delta X_{i}+\gamma_{j l}+\epsilon_{i l}
$$

The fixed effects transformation to eliminate closing-connected firm fixed effects results in the following regression equation

$$
G_{j, l}=R_{j, l}^{L i n k}-R_{j, l}^{n o L i n k}=\beta^{0} L_{i l}+\beta^{x} \bar{X}_{j l}^{L i n k}+\delta\left(\bar{X}_{j l}^{L i n k}-\bar{X}_{j l}^{n o L i n k}\right)+u_{i l}
$$

where $\bar{X}_{j l}^{L i n k}$ denotes the mean value of $X_{i}$ for individuals displaced from closing firm $j$ with links to connected firm $l$, and $\bar{X}_{j l}^{n o L i n k}$ is the equivalent for individuals without links.

Table 10 shows the estimation results for specifications including the same population groups that were investigated in the job search analysis in Tables 7 and 8 . Columns (1) to (7) present results from separate regressions entering one of the covariates at a time. Column (8) shows results from a regression model that includes the full set of covariates simultaneously.

Interestingly, the heterogeneity in hiring probabilities for workers with a link to the connected firm resembles our results on the job seekers' side. We find no difference in hiring probabilities by gender. Blue collar workers, although they are more likely to be hired by a connected firm do not benefit as much from a link to a former coworker as white collar workers. The same holds for 
workers with Austrian nationality. Comparing hiring probabilities across different age groups, we confirm that network effects are more important for older workers. Survey evidence typically finds that informal job search methods are most widely used by individuals with low socioeconomy status (Topa, 2011), such as blue collar workers or migrants. In contrast, our results imply that the productivity of work-related networks is highest for natives, higher qualified, and older workers.

\section{Conclusion}

In this paper we have investigated the effects of work-related social networks on job search outcomes of displaced workers. We implemented our definition of former coworker-networks in large-scale register data from the universe of Austrian social security registers, which provides us with very detailed network characteristics for a large sample of workers displaced from closing firms. An advantage of our setup is that we can study network effects from the job seekers' perspective and from the hiring firm's perspective. This allows us to empirically distinguish between several mechanisms through which social networks affect labor market outcomes.

Specifically, we identified three potential mechanisms in section 2. Our empirical evidence provides the least support the preference mechanism, by which social networks do not foster the exchange job related information but directly affect a worker's taste for work or leisure. We find that the types of firms in which contacts are employed matters more than just the fact that contacts are employed and thus we conclude that information transmission is an important component of the network effects. The remaining two mechanisms differ in the type of information that is transmitted by the network. We find strong evidence in favor of job referrals as the driving force of social network effects. Rather than exchanging general information about job opportunities or search strategies, network members seem to produce concrete referrals to vacancies in their own firms.

With respect to heterogeneity of network effects, we find that work-related social contacts are most productive for higher qualified or older individuals and for natives. These groups might be more experienced in exploiting work-related contacts. Alternatively job referrals might be a stronger signal to the employer, particularly for older workers.

A large literature documents that job displacements lead to large and persistent earnings losses for affected workers, which are particularly severe during recessions (Von Wachter and Davis, 2011). Our results show that individuals with good connections are protected from the 
adverse effects to a certain extent, especially if they manage to join one of their former coworkers in a high wage firm. Policy implications from this result are to encourage displaced workers to contact their social networks and to concentrate counseling and placement efforts on individuals with poor social connections, who may disadvantaged by employers favoring referred applicants (DiTomaso, 2013). 


\section{References}

Aslund, O., Hensvik, L., Nordström Skans, O., 2014. Seeking similarity: How immigrants and natives manage in the labor market. Journal of Labor Economics 32 (3).

Bandiera, O., Barankay, I., Rasul, I., 2009. Social connections and incentives in the workplace: Evidence from personnel data. Econometrica 77 (4), 1047-1094.

Bayer, P., Ross, S., Topa, G., 2008. Place of work and place of residence: informal hiring networks and labor market outcomes. Journal of Political Economy 116(6), 1150-1196.

Brown, M., Setren, E., Topa, G., 2012. Do informal referrals leads to better matches? evidence from a firm's employee referral system. Staff Report, Federal Reserve Bank of New York 568.

Burks, S., Cowgill, B., Hoffman, M., Housman, M., 2014. The Facts About Referrals: Toward an Understanding of Employee Referral Networks. Mimeo, University of Toronto Rotman School of Management.

Calvo-Armengol, A., Jackson, M. O., 2004. The effects of social networks on employment and inequality. The American Economic Review 94(3), 426-454.

Castilla, E. J., 2005. Social networks and employee performance in a call center. American Journal of Sociology 110, 1243-83.

Cingano, F., Rosolia, A., 2012. People I know: Job search and social networks. Journal of Labor Economics 30 (2), 291-332.

DiTomaso, N., 2013. The American Non-Dilemma: Racial Inequality Without Racism. Russell Sage Foundation.

Dustmann, C., Glitz, A., Schönberg, U., 2012. Referral-based job search networks. Mimeo, University College London.

Eppl, R., Mahringer, H., Weber, A., 2014. The job search strategies and job search success of unemployed workers. Mimeo, WIFO Vienna.

Fink, M., Kalkbrenner, E., Weber, A., Zulehner, C., 2010. Extracting firm information form administrative records: The ASSD Firm Panel. NRN: The Austrian Center for Labor Economics and the Analysis of the Welfare State Working Paper 1004. 
Fink, M., Segalla, E., Weber, A., 2014. Long-term career effects of job-loss during the 1980s recession in austria. Mimeo, Mannheim University.

Giuliano, L., Levine, D., Leonard, J., 2009. Manager race and the race of new hires. Journal of Labor Economics 27 (4), 589-631.

Glitz, A., 2013. Coworker networks in the labour market. IZA Discussion paper, No. 7392, 1-41.

Granovetter, M. S., 1974. Getting a Job: A Study of Contacts and Careers. Harvard University Press, Cambridge.

Hawranek, F., Schanne, N., 2014. Your very private job agency: Job referrals based on residential location networks. IAB Discussion Paper 1/2014, Institute for Employment Research, Nuremberg.

Hellerstein, J., McInerney, M., Neumark, D., 2011. Neighbors and coworkers: The importance of residential labor market networks. Journal of Labor Economics 29 (4), 659-695.

Hensvik, L., Nordström Skans, O., 2013. Social networks, employee selection and labor market outcomes. IFAU Working Paper, 2013:15, Uppsala.

Holzer, H. J., 1987. Human Resources and the Performance of the Firm. Industrial Relations Research Association, Madison, WI, Ch. Hiring Procedures in the Firm:Their Economic Determinants and Outcomes.

Ioannides, Y. M., Loury, L. D., 2004. Job information networks, neighborhood effects, and inequality. Journal of Economic Literature 42 (4), 1056-1093.

Jacobson, L., LaLonde, R., Sullivan, D., 1993. Earnings losses of displaced workers. American Economic Review 83 (4), 685-709.

Jovanovic, B., 1979. Job matching and the theory of turnover. Journal of Political Economy $87(5), 972-990$.

Kramarz, F., Nordström Skans, O., 2013. When strong ties are strong: Networks and youth labor market entry. CEPR Discussion Paper DP9620.

Kramarz, F., Thesmar, D., 2013. Social networks in the boardroom. Journal of the European Economic Association 11 (4), 780-807. 
Marmaros, D., Sacerdote, B., 2002. Peer and social networks in job search. European Economic Review $46(4 / 5), 870-879$.

Marsden, P. V., 2001. Social Capital: Theory and Research. Aldine Transaction, Ch. Interpersonal Ties, Social Capital, and Employer Staffing Practices, pp. 105 - 125.

Mas, A., Moretti, E., 2009. Peers at work. American Economic Review 99 (1), 112-145.

Montgomery, J. D., 1991. Social networks and labor -market outcome: Toward an economic analysis. The American Economic Review 81 (5), 10408-1418.

Pellizzari, M., 2010. Do friends and relatives really help in getting a good job? Industrial and Labor Relations Review 63 (3), 1-19.

Rees, A., 1966. Information networks in labor markets. The American Economic Review 56 (1), $559-566$.

Simon, C. J., Warner, J. T., 1992. Matchmaker, matchmaker: The effect of old boy networks on job match quality, earnings, and tenure. Journal of Labor Economics 10 (3), 306-30.

Topa, G., 2011. Handbook of Social Economics. Vol. 1B. North-Holland, Ch. Labor Markets and Referrals, pp. 1194-1221.

Von Wachter, T., Davis, S. J., 2011. Recessions and the Costs of Job Loss. Brooking Papers on Economic Activity 43, 1-72.

Von Wachter, T., Song, J., Manchester, J., 2011. Long-term earnings losses due to mass-layoffs during the 1982 recession: An analysis using longitudinal administrative data from 1974 to 2008. Mimeo, Columbia University.

Zweimüller, J., Winter-Ebmer, R., Lalive, R., Kuhn, A., Wuellrich, J.-P., Ruf, O., Büchi, S., 2009. Austrian Social Security Database. NRN: The Austrian Center for Labor Economics and the Analysis of the Welfare State Working Paper 0903. 
Table 1: Summary Statistics : Displaced Workers

\section{Individual Characteristics}

Female

Age

Blue Collar Worker

Austrian Nationality

Tenure (in years)

Employed over Last 5 Years

Unemployed over Last 5 Years

Number of Firms over Last 5 Years

Average Firm Size over Last 5 Years

Size of Closing0.3cm Firm in Final Quarter

Mean Median Std. Dev.

$\begin{array}{ccc}0.41 & & 0.49 \\ 36.8 & 36.0 & 9.5 \\ 0.53 & & 0.50 \\ 0.91 & & 0.28 \\ 4.87 & 2.92 & 4.84 \\ 4.27 & 4.90 & 1.06 \\ 0.14 & 0.00 & 0.35 \\ 1.92 & 2 & 1.20 \\ 50.29 & 19.28 & 105.4 \\ 13.71 & 7 & 20.52\end{array}$

\section{Network Characteristics}

Network Size

$158.3 \quad 44 \quad 339.0$

Share of Network Members who are

Female

Blue Collar Workers

Austrian Nationality

Same Gender as Displaced Worker

Same Age Group

Same Occupation

Same Nationality

\section{Network Employment Characteristics}

Share of Network Members who are

$\begin{array}{llll}\text { Employed } & 0.56 & 0.57 & 0.18 \\ \text { Employed in the Same Industry } & 0.19 & 0.13 & 0.19 \\ \text { Employed in Net Hiring Firms } & 0.24 & 0.21 & 0.18 \\ \text { Employed in Above Median Wage Firms } & 0.30 & 0.26 & 0.21\end{array}$

Observations

$\begin{array}{lll}0.40 & 0.34 & 0.31 \\ 0.62 & 0.76 & 0.35 \\ 0.92 & 0.96 & 0.11 \\ 0.68 & 0.75 & 0.27 \\ 0.28 & 0.25 & 0.18 \\ 0.69 & 0.81 & 0.31 \\ 0.86 & 0.95 & 0.23\end{array}$

Note: Sample includes workers displaced from firm closures in 1980-2007. Employed in same industry refers to the share of network members who are employed in the same two digit industry as the closing firm. Employed in net hiring firms refers to the share of network members who are employed in firms that increase their absolute employment level during the quarter of displacement. Employed in above median wage firms refers to the share of network members who are employed in firms that pay average wages above median of the firm level distribution. 
Table 2: Firm Characteristics

Mean Median Std.Dev.

\section{Closing Firms}

Number of Displaced Workers

$\begin{array}{ccc}5.4 & 4 & 6.7 \\ 23.9 & 13 & 51.4 \\ 10.0 & 7.5 & 8.4 \\ 1.95 & 1.00 & 1.12 \\ 0.31 & & 0.46 \\ 0.19 & 0.39 & \\ 0.16 & 0.37 & \\ 0.24 & & 0.43 \\ 0.14 & & 0.34 \\ 0.19 & & 0.39\end{array}$

Firm Size at Maximum

0.39

Firm Network Characteristics (per closing firm)

Number of Connected Firms

175.3

$55 \quad 317.9$

Average Size

154.4

147.5

97.8

Average Wage Quartile

2.39

2.43

0.49

Share Same Industry

0.23

0.16

0.21

Share Same Region

0.55

0.60

0.30

Number of Closing Firms

\section{Per Closing - Connected Firm Pair}

Individuals with Links 
Table 3: Job Search Outcomes

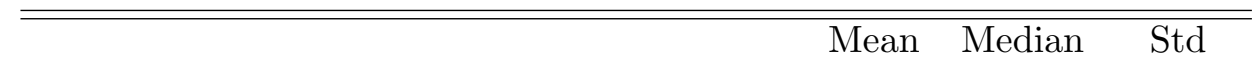

All Job Seekers $(\mathrm{N}=151,432)$

Find New Job in One Year

$\begin{array}{ccc}0.86 & & 0.34 \\ 83.19 & 2 & 131.32 \\ 0.49 & & 0.50 \\ 0.33 & & 0.47 \\ & & \\ 373.8 & 137 & 655.9 \\ 58.2 & 22 & 110.7 \\ 0.40 & 0.24 & 0.37 \\ 0.21 & & 0.40\end{array}$

Time to Next Job in Days (Censored at 365)

New Job Immediately

Mean Median Std

Unemployed

Links to Firm Network

Number of Connected Firms

Number of Connected Firms with Link

Share of Connected Firms with Link

Hired by Connected Firm

Successful Job Seekers (N = 130,477)

Time to Next Job Days

$\begin{array}{ccc}37.93 & 1 & 72.20 \\ 0.009 & 0.015 & 0.301 \\ 0.52 & & 0.50 \\ 0.80 & & 2.83 \\ 0.07 & & 0.25\end{array}$

Log Wage Gain

New Job in Same Industry

New Job in Same Region

0.07

0.25

Links to Firm Network

Number of Connected Firms

$\begin{array}{ccc}383.0 & 150 & 636.8 \\ 60.7 & 24 & 110.7 \\ 0.39 & 0.24 & 0.36 \\ 0.24 & & 0.43 \\ 0.19 & & 0.39\end{array}$

Note: Sample includes workers displaced from firm closures in 1980-2007. Successful job seekers are defined as displaced workers who find a new job within 365 days. A job in an old firm refers to a firm where the displaced worker was employed during the last 5 years. The firm network for each closing firm consists of a set of connected firm where former coworkers of the displaced individuals are employed at the firm closure date. Industries are defined at the 2 digit NACE level. Regions are defined at the level of 35 NUTS3 districts. 
Table 4: Effect of Network Characteristics on Job Finding Rates

\begin{tabular}{|c|c|c|c|c|c|}
\hline & (1) & $(2)$ & $(3)$ & (4) & $(5)$ \\
\hline Log Network Size & $\begin{array}{c}0.016 \\
(0.004)\end{array}$ & $\begin{array}{c}0.009 \\
(0.004)\end{array}$ & $\begin{array}{c}0.008 \\
(0.004)\end{array}$ & $\begin{array}{c}0.008 \\
(0.004)\end{array}$ & $\begin{array}{c}0.008 \\
(0.004)\end{array}$ \\
\hline $\begin{array}{l}\text { Share of Network Members } \\
\text { Employed }\end{array}$ & $\begin{array}{c}0.195 \\
(0.022)\end{array}$ & $\begin{array}{c}0.109 \\
(0.025)\end{array}$ & $\begin{array}{c}0.071 \\
(0.026)\end{array}$ & $\begin{array}{c}0.097 \\
(0.026)\end{array}$ & $\begin{array}{c}0.099 \\
(0.027)\end{array}$ \\
\hline Employed in Same Industry & & $\begin{array}{c}0.134 \\
(0.021)\end{array}$ & $\begin{array}{c}0.136 \\
(0.021)\end{array}$ & $\begin{array}{c}0.133 \\
(0.021)\end{array}$ & $\begin{array}{c}0.131 \\
(0.021)\end{array}$ \\
\hline Employed at Net Hiring Firms & & & $\begin{array}{c}0.086 \\
(0.018)\end{array}$ & & \\
\hline Employed at Net Hiring Firms in 2 Qtrs. & & & & $\begin{array}{c}0.074 \\
(0.024)\end{array}$ & \\
\hline Employed at Above Med. Wage Firms & & & & & $\begin{array}{c}0.017 \\
(0.019)\end{array}$ \\
\hline Observations & 151,432 & 151,432 & 151,432 & 151,432 & 151,432 \\
\hline
\end{tabular}

Note: Estimation results from Cox regressions where the dependent variable is the hazard to a new job in days. Standard errors in parenthesis. The estimation sample includes workers displaced from firm closures in 1980-2007. In each column we add a different measure of the network employment rate as indicated. All specifications control for the following covariates: gender, age (quintiles), marital status, Austrian nationality, education (5 groups), blue collar occupation, tenure in last job (quintiles), employment days in last two years, days employed last 5 years (quintiles), days employed last 15 years (quintiles), days claiming UI in the last 3 and last 5 years, wage before job loss (quintiles), number of employers in the last 5 years, average firm size over the last 5 years (quintiles). All specifications allow for closing firm specific baseline hazards. 
Table 5: Wage Growth: Effect of Network Characteristics, Men

\begin{tabular}{|c|c|c|c|c|c|}
\hline Log Network Size & $\begin{array}{c}0.002 \\
(0.001)\end{array}$ & $\begin{array}{c}0.002 \\
(0.002)\end{array}$ & $\begin{array}{c}0.002 \\
(0.002)\end{array}$ & $\begin{array}{c}0.002 \\
(0.002)\end{array}$ & $\begin{array}{c}0.000 \\
(0.002)\end{array}$ \\
\hline $\begin{array}{l}\text { Share of Network Members } \\
\text { Employed }\end{array}$ & $\begin{array}{c}0.024 \\
(0.013)\end{array}$ & $\begin{array}{c}0.024 \\
(0.015)\end{array}$ & $\begin{array}{c}0.023 \\
(0.016)\end{array}$ & $\begin{array}{c}0.023 \\
(0.015)\end{array}$ & $\begin{array}{l}-0.009 \\
(0.017)\end{array}$ \\
\hline Employed in Same Industry & & $\begin{array}{l}-0.000 \\
(0.011)\end{array}$ & $\begin{array}{l}-0.000 \\
(0.011)\end{array}$ & $\begin{array}{l}-0.000 \\
(0.011)\end{array}$ & $\begin{array}{l}-0.009 \\
(0.012)\end{array}$ \\
\hline Employed at Net Hiring Firms & & & $\begin{array}{c}0.003 \\
(0.010)\end{array}$ & & \\
\hline Employed at Net Hiring Firms in 2 Qtrs. & & & & $\begin{array}{c}0.002 \\
(0.014)\end{array}$ & \\
\hline Employed at Above Med. Wage Firms & & & & & $\begin{array}{c}0.056 \\
(0.012)\end{array}$ \\
\hline Observations & 82,948 & 82,948 & 82,948 & 82,948 & 82,948 \\
\hline
\end{tabular}

Note: Estimation results from linear regressions where the dependent variable is the difference in log wages between the last job and the new job. The sample is restricted to males displaced from firm closures in 1980-2007, who find a new job within 365 days of firm closure. Standard errors in parenthesis. In each column we add a different measure of network employment rate as indicated. All estimations include closing firm fixed effects. For list of additional covariates see Table 4.

Table 6: Wage Growth: Effect of Network Characteristics, Women

\begin{tabular}{|c|c|c|c|c|c|}
\hline Log Network Size & $\begin{array}{c}0.003 \\
(0.002)\end{array}$ & $\begin{array}{c}0.001 \\
(0.002)\end{array}$ & $\begin{array}{c}0.001 \\
(0.002)\end{array}$ & $\begin{array}{c}0.001 \\
(0.002)\end{array}$ & $\begin{array}{l}-0.000 \\
(0.002)\end{array}$ \\
\hline $\begin{array}{l}\text { Share of Network Members } \\
\text { Employed }\end{array}$ & $\begin{array}{c}0.020 \\
(0.018)\end{array}$ & $\begin{array}{l}-0.006 \\
(0.020)\end{array}$ & $\begin{array}{l}-0.022 \\
(0.022)\end{array}$ & $\begin{array}{l}-0.009 \\
(0.021)\end{array}$ & $\begin{array}{l}-0.025 \\
(0.022)\end{array}$ \\
\hline Employed in Same Industry & & $\begin{array}{c}0.041 \\
(0.018)\end{array}$ & $\begin{array}{c}0.042 \\
(0.018)\end{array}$ & $\begin{array}{c}0.041 \\
(0.018)\end{array}$ & $\begin{array}{c}0.036 \\
(0.018))\end{array}$ \\
\hline Employed at Net Hiring Firms & & & $\begin{array}{c}0.037 \\
(0.016)\end{array}$ & & \\
\hline Employed at Net Hiring Firms in 2 Qtrs. & & & & $\begin{array}{c}0.022 \\
(0.021)\end{array}$ & \\
\hline Employed at Above Med. Wage Firms & & & & & $\begin{array}{c}0.041 \\
(0.016))\end{array}$ \\
\hline Observations & 55,885 & 55,885 & 55,885 & 55,885 & 55,885 \\
\hline
\end{tabular}

Note: Estimation results from linear regressions where the dependent variable is the difference in log wages between the last job and the new job. The sample is restricted to females displaced from firm closures in 1980-2007, who find a new job within 365 days of firm closure. Standard errors in parenthesis. In each column we add a different measure of network employment rate as indicated. All estimations include closing firm fixed effects. For list of additional covariates see Table 4. 
Table 7: Job Finding: Effect of Similar Charcteristics

\begin{tabular}{lcccccc}
\hline & Female & Male & Blue Collar & White Collar & Austrian & Non-Austrian \\
\hline Log Network Size & 0.027 & 0.026 & -0.002 & 0.052 & 0.033 & -0.034 \\
& $(0.009)$ & $(0.008)$ & $(0.008)$ & $(0.008)$ & $(0.006)$ & $(0.021)$ \\
Share of Network Members & & & & & & \\
Employed Same Group & 0.047 & 0.048 & 0.020 & 0.080 & 0.059 & 0.005 \\
& $(0.009)$ & $(0.009)$ & $(0.010)$ & $(0.010)$ & $(0.017)$ & $(0.016)$ \\
Employed Opposite Group & 0.055 & 0.033 & 0.014 & 0.087 & 0.023 & 0.003 \\
& $(0.012)$ & $(0.009)$ & $(0.011)$ & $(0.013)$ & $(0.008)$ & $(0.021)$ \\
Unemployed Same Group & 0.031 & 0.004 & -0.009 & 0.04 & 0.024 & -0.01 \\
& $(0.011)$ & $(0.009)$ & $(0.011)$ & $(0.010)$ & $(0.017)$ & $(0.018)$ \\
\hline Observations & 62,766 & 88,666 & 80,604 & 70,828 & 138,010 & 13,422 \\
\hline
\end{tabular}

Note: Estimation results from Cox regressions where the dependent variable is the hazard to a new job in days. Standard errors in parenthesis. The columns present estimation results for different subsamples of workers displaced from firm closures in 1980-2007. Standard errors in parenthesis. "Employed Same Group" refers to the share of network members from the same group as the column head who are employed at the time of firm closure. Employment share variables are standardized with mean zero and sd equal. All estimations allow for closing firm specific baseline hazards. For list of additional covariates see Table 4

Table 8: Job Finding: Effect of Similar Age Groups

\begin{tabular}{lcccc}
\hline & Below 29 & 29 to 36 & 36 to 43 & Above 43 \\
\hline Log Network Size & 0.078 & -0.001 & 0.019 & -0.009 \\
& $(0.013)$ & $(0.014)$ & $(0.013)$ & $(0.014)$ \\
Share of Network Members & & & & \\
Employed Same Group & 0.06 & 0.021 & 0.013 & 0.054 \\
& $(0.010)$ & $(0.009)$ & $(0.009)$ & $(0.011)$ \\
Employed Age $<29$ & & 0.022 & 0.048 & 0.084 \\
& & $(0.011)$ & $(0.012)$ & $(0.015)$ \\
Employed Age 29-35 & 0.002 & & 0.019 & 0.036 \\
& $(0.008)$ & & $(0.009)$ & $(0.012)$ \\
Employed Age 36 - 43 & 0.02 & 0.012 & & 0.041 \\
& $(0.009)$ & $(0.009)$ & & $(0.011)$ \\
Employed Age $>43$ & 0.022 & 0.013 & 0.024 & \\
& $(0.009)$ & $(0.010)$ & $(0.010)$ & \\
Unemployed Same Group & 0.014 & 0.001 & 0.006 & 0.042 \\
& $(0.012)$ & $(0.010)$ & $(0.011)$ & $(0.015)$ \\
\hline Observations & 36,030 & 35,244 & 38,404 & 41,754
\end{tabular}

Note: Estimation results from Cox regressions where the dependent variable is the hazard to a new job in days. Standard errors in parenthesis. The columns present estimation results for different subsamples of workers displaced from firm closures in 1980-2007. "Employed Same Group" refers to the share of network members from the same group as the column head who are employed at the time of firm closure. Employment share variables are standardized with mean zero and sd equal. All estimations allow for closing firm specific baseline hazards. For list of additional covariates see Table 4. 
Table 9: Hiring Probabilities

\begin{tabular}{lccccc}
\hline & All & Vienna & Same industry & Year > 1995 & \# Layoffs > 10 \\
\hline coeff. $\beta$ & 0.00067 & 0.00050 & 0.00149 & 0.00056 & 0.00053 \\
& $(0.00003)$ & $(0.00004)$ & $(0.00009)$ & $(0.00003)$ & $(0.00005)$ \\
& 24.96 & 12.82 & 15.78 & 17.2 & 9.9 \\
$R_{j, l}^{\text {Link }}$ & 0.00115 & 0.00095 & 0.00283 & 0.00100 & 0.00109 \\
$R_{j, l}^{\text {noLink }}$ & $(0.00001)$ & $(0.00002)$ & $(0.00004)$ & $(0.00001)$ & $(0.00002)$ \\
& 0.00047 & 0.00045 & 0.00134 & 0.00044 & 0.00056 \\
Ratio & $(0.00001)$ & $(0.00001)$ & $(0.00003)$ & $(0.00001)$ & $(0.00001)$ \\
Observations & $5,711,461$ & $2,299,824$ & $1,055,871$ & $3,491,092$ & $2,430,651$
\end{tabular}

Note: Estimation for the probability of finding a new job in a connected firm from linear probability model. The parameter $\beta$ measures the effect of having a direct link via a former coworker. Observations are pairs of closing and connected firms. Dependent variable see equation 4. The columns present estimation results for different subsamples. Standard errors in parenthesis. All estimations are weighted by the number of links between closing and connected firms. Standard errors are clustered at the closing firm level. 
Table 10: Hiring Probabilities: Heterogeneity

\begin{tabular}{|c|c|c|c|c|c|c|c|c|}
\hline & (1) & $(2)$ & (3) & (4) & $(5)$ & (6) & (7) & $(8)$ \\
\hline coeff. $\beta^{0}$ & $\begin{array}{c}0.00066 \\
(0.00004)\end{array}$ & $\begin{array}{c}0.00090 \\
(0.00004)\end{array}$ & $\begin{array}{c}0.00023 \\
(0.00011)\end{array}$ & $\begin{array}{c}0.00076 \\
(0.00005)\end{array}$ & $\begin{array}{c}0.00078 \\
(0.00005)\end{array}$ & $\begin{array}{c}0.00059 \\
(0.00004)\end{array}$ & $\begin{array}{c}0.00057 \\
(0.00004)\end{array}$ & $\begin{array}{c}0.00042 \\
(0.00019)\end{array}$ \\
\hline Female & $\begin{array}{l}-0.00005 \\
(0.00011)\end{array}$ & & & & & & & $\begin{array}{c}0.00002 \\
(0.00012)\end{array}$ \\
\hline Link $\times$ Female & $\begin{array}{c}0.00002 \\
(0.00008)\end{array}$ & & & & & & & $\begin{array}{l}-0.00009 \\
(0.00008)\end{array}$ \\
\hline Blue Collar & & $\begin{array}{c}0.00022 \\
(0.00010)\end{array}$ & & & & & & $\begin{array}{c}0.00021 \\
(0.00011)\end{array}$ \\
\hline Link $\times$ Blue Collar & & $\begin{array}{l}-0.00040 \\
(0.00007)\end{array}$ & & & & & & $\begin{array}{l}-0.00044 \\
(0.00008)\end{array}$ \\
\hline Austrian & & & $\begin{array}{l}-0.00050 \\
(0.00014)\end{array}$ & & & & & $\begin{array}{l}-0.00036 \\
(0.00015)\end{array}$ \\
\hline Link $\times$ Austrian & & & $\begin{array}{c}0.00049 \\
(0.00013)\end{array}$ & & & & & $\begin{array}{c}0.00032 \\
(0.00014)\end{array}$ \\
\hline Age $<29$ & & & & $\begin{array}{c}0.00010 \\
(0.00011)\end{array}$ & & & & \\
\hline Link $\times$ Age $<29$ & & & & $\begin{array}{l}-0.00030 \\
(0.00011)\end{array}$ & & & & \\
\hline Age $29-35$ & & & & & $\begin{array}{c}0.00040 \\
(0.00011)\end{array}$ & & & $\begin{array}{c}0.00020 \\
(0.00011)\end{array}$ \\
\hline Link $\times$ Age $29-35$ & & & & & $\begin{array}{l}-0.00045 \\
(0.00012)\end{array}$ & & & $\begin{array}{l}-0.00009 \\
(0.00011)\end{array}$ \\
\hline Age $36-43$ & & & & & & $\begin{array}{c}0.00013 \\
(0.00012)\end{array}$ & & $\begin{array}{l}-0.00022 \\
(0.00011)\end{array}$ \\
\hline Link $\times$ Age $36-43$ & & & & & & $\begin{array}{c}0.00035 \\
(0.00012)\end{array}$ & & $\begin{array}{c}0.00055 \\
(0.00012)\end{array}$ \\
\hline Age $>43$ & & & & & & & $\begin{array}{l}-0.00029 \\
(0.00017)\end{array}$ & $\begin{array}{l}-0.00029 \\
(0.00018)\end{array}$ \\
\hline Link $\times$ Age $>43$ & & & & & & & $\begin{array}{c}0.00040 \\
(0.00017)\end{array}$ & $\begin{array}{c}0.00057 \\
(0.00018)\end{array}$ \\
\hline Observations & $5,711,461$ & $5,711,461$ & $5,711,461$ & $5,711,461$ & $5,711,461$ & $5,711,461$ & $5,711,461$ & $5,711,461$ \\
\hline
\end{tabular}

Note: Estimations for the probability of finding a new job in a connected firm from linear probability models. Observations are pairs of closing and connected firms. For the definition of the dependent variable see equation 6 . Columns (1) - (7) present estimation results from separated regressions where one covariate is entered in the model at a time. Column (8) presents estimation results from a single regression entering all covariates simultaneously. Standard errors in parenthesis. Coefficients show the main effects for covariates and the interaction between covariate and link indicator. Estimations are weighted by the number of links between closing and connected firms. Standard errors are clustered at the closing firm level. 


\section{A Appendix Tables - Not for Publication}

Table A.1: Effect of Network Characteristics on Probability of Finding a Job within 3 Months

\begin{tabular}{|c|c|c|c|c|c|}
\hline & $(1)$ & $(2)$ & (3) & $(4)$ & (5) \\
\hline Log Network Size & $\begin{array}{c}0.005 \\
(0.002)\end{array}$ & $\begin{array}{c}0.001 \\
(0.002)\end{array}$ & $\begin{array}{c}0.000 \\
(0.002)\end{array}$ & $\begin{array}{c}0.001 \\
(0.002)\end{array}$ & $\begin{array}{c}0.001 \\
(0.002)\end{array}$ \\
\hline $\begin{array}{l}\text { Share of Network Members } \\
\text { Employed }\end{array}$ & $\begin{array}{c}0.072 \\
(0.012)\end{array}$ & $\begin{array}{c}0.021 \\
(0.014)\end{array}$ & $\begin{array}{c}0.004 \\
(0.014)\end{array}$ & $\begin{array}{c}0.017 \\
(0.014)\end{array}$ & $\begin{array}{c}0.015 \\
(0.015)\end{array}$ \\
\hline Employed in Same Industry & & $\begin{array}{c}0.080 \\
(0.011)\end{array}$ & $\begin{array}{c}0.081 \\
(0.011)\end{array}$ & $\begin{array}{c}0.080 \\
(0.011)\end{array}$ & $\begin{array}{c}0.079 \\
(0.011)\end{array}$ \\
\hline Employed at Net Hiring Firms & & & $\begin{array}{c}0.040 \\
(0.010)\end{array}$ & & \\
\hline Employed at Net Hiring Firms in 2 Qtrs. & & & & $\begin{array}{c}0.028 \\
(0.013)\end{array}$ & \\
\hline Employed at Above Med. Wage Firms & & & & & $\begin{array}{c}0.011 \\
(0.011)\end{array}$ \\
\hline Observations & 151,432 & 151,432 & 151,432 & 151,432 & 151,432 \\
\hline
\end{tabular}

Note: Estimation results from OLS regressions where the dependent variable is a dummy variable equal to one if the individual finds a new job within 90 days. The mean of the dependent variable is 0.72 , standard deviation 0.45 . Standard errors in parenthesis. The estimation sample includes workers displaced from firm closures in 1980-2007. In each column we add a different measure of the network employment rate as indicated. All specifications allow for closing firm specific baseline hazards. For list of additional covariates see Table 4. 
Table A.2: Job Finding Rate: Effect of Time Varying Network Characteristics

\begin{tabular}{|c|c|c|c|c|c|}
\hline & (1) & $(2)$ & (3) & $(4)$ & $(5)$ \\
\hline Log Network Size & $\begin{array}{c}0.018 \\
(0.004)\end{array}$ & $\begin{array}{c}0.009 \\
(0.004)\end{array}$ & $\begin{array}{c}0.009 \\
(0.004)\end{array}$ & $\begin{array}{c}0.009 \\
(0.004)\end{array}$ & $\begin{array}{c}0.008 \\
(0.004)\end{array}$ \\
\hline $\begin{array}{l}\text { Share of Network Members } \\
\text { Employed }\end{array}$ & $\begin{array}{c}0.171 \\
(0.022)\end{array}$ & $\begin{array}{c}0.078 \\
(0.025)\end{array}$ & $\begin{array}{c}0.033 \\
(0.026)\end{array}$ & $\begin{array}{c}0.065 \\
(0.025)\end{array}$ & $\begin{array}{c}0.019 \\
(0.028)\end{array}$ \\
\hline Employed in Same Industry & & $\begin{array}{c}0.146 \\
(0.021)\end{array}$ & $\begin{array}{c}0.148 \\
(0.021)\end{array}$ & $\begin{array}{c}0.145 \\
(0.021)\end{array}$ & $\begin{array}{c}0.144 \\
(0.021)\end{array}$ \\
\hline Employed in Net Hiring Firms & & & $\begin{array}{c}0.101 \\
(0.018)\end{array}$ & & $\begin{array}{c}0.100 \\
(0.018)\end{array}$ \\
\hline Employed in Net Hiring Firms in 2 Qtrs. & & & & $\begin{array}{c}0.078 \\
(0.024)\end{array}$ & \\
\hline Employed in Above Med. Wage Firms & & & & & $\begin{array}{c}0.027 \\
(0.019)\end{array}$ \\
\hline Observations & 247,926 & 247,926 & 247,926 & 247,926 & 247,926 \\
\hline
\end{tabular}

Note: Estimation results from Cox regressions where the dependent variable is the hazard to a new job in days. Standard errors in parenthesis. The estimation sample includes workers displaced from firm closures in 1980-2007. In each column we add a different measure of the network employment rate as indicated. Share of network members employed, share of network members employed in same industry, and share of network members employed in net hiring firms are included as time varying variables, changing at the quarterly level. All estimations allow for closing firm specific baseline hazards. For list of additional covariates see Table 4.

Table A.3: Job Finding Rate: Excluding Seasonal Industries

\begin{tabular}{|c|c|c|c|c|c|}
\hline & $(1)$ & $(2)$ & $(3)$ & $(4)$ & $(5)$ \\
\hline Log Network Size & $\begin{array}{c}0.021 \\
(0.004)\end{array}$ & $\begin{array}{c}0.014 \\
(0.004)\end{array}$ & $\begin{array}{c}0.013 \\
(0.004)\end{array}$ & $\begin{array}{c}0.014 \\
(0.004)\end{array}$ & $\begin{array}{c}0.014 \\
(0.004)\end{array}$ \\
\hline $\begin{array}{l}\text { Share of Network Members } \\
\text { Employed }\end{array}$ & $\begin{array}{c}0.229 \\
(0.025)\end{array}$ & $\begin{array}{c}0.151 \\
(0.029)\end{array}$ & $\begin{array}{c}0.114 \\
(0.031)\end{array}$ & $\begin{array}{c}0.135 \\
(0.030)\end{array}$ & $\begin{array}{c}0.142 \\
(0.032)\end{array}$ \\
\hline Employed in Same Industry & & $\begin{array}{c}0.12 \\
(0.024)\end{array}$ & $\begin{array}{c}0.122 \\
(0.024)\end{array}$ & $\begin{array}{c}0.12 \\
(0.024)\end{array}$ & $\begin{array}{c}0.118 \\
(0.024)\end{array}$ \\
\hline Employed in Net Hiring Firms & & & $\begin{array}{c}0.084 \\
(0.021)\end{array}$ & & \\
\hline Employed in Net Hiring Firms in 2 Qtrs. & & & & $\begin{array}{c}0.096 \\
(0.027)\end{array}$ & \\
\hline Employed in Above Med. Wage Firms & & & & & $\begin{array}{c}0.015 \\
(0.022)\end{array}$ \\
\hline Observations & 109,539 & 109,539 & 109,539 & 109,539 & 109,539 \\
\hline
\end{tabular}

Note: Estimation results from Cox regressions where the dependent variable is the hazard to a new job in days. Standard errors in parenthesis. The estimation sample includes workers displaced from firm closures in 1980-2007 excluding firms in agriculture, construction, and tourism industries. In each column we add a different measure of the network employment rate as indicated. Share of network members employed, share of network members employed in same industry, and share of network members employed in net hiring firms are included as time varying variables, changing at the quarterly level. All estimations allow for closing firm specific baseline hazards. For list of additional covariates see Table 4. 
Table A.4: Hiring Probabilities: unweighted

\begin{tabular}{lccccc}
\hline & All & Vienna & Same industry & Year > 1995 & \# Layoffs > 10 \\
\hline coeff. $\beta$ & 0.00062 & 0.00047 & 0.00133 & 0.00047 & 0.00040 \\
& $(0.00001)$ & $(0.00002)$ & $(0.00005)$ & $(0.00002)$ & $(0.00002)$ \\
t-stat & 45.47 & 25.07 & 24.18 & 30.79 & 22.75 \\
& & & & & \\
$R_{j, l}^{\text {Link }}$ & 0.00087 & 0.00066 & 0.00214 & 0.00070 & 0.00058 \\
$R_{j, l}^{\text {noLink }}$ & $(0.00001)$ & $(0.00002)$ & $(0.00005)$ & $(0.00002)$ & $(0.00002)$ \\
& 0.00025 & 0.00020 & 0.00081 & 0.00023 & 0.00017 \\
Ratio & $(0.00001)$ & $(0.00001)$ & $(0.00003)$ & $(0.00001)$ & $(0.00001)$ \\
& & & & & 3.38 \\
Observations & $4,168,303$ & $1,704,759$ & 662,346 & $2,579,934$ & $1,350,377$
\end{tabular}

Note: Estimation for the probability of finding a new job in a connected firm from linear probability model. The parameter $\beta$ measures the effect of having a direct link via a former coworker. Observations are pairs of closing and connected firms. Dependent variable see equation 4 . The columns present estimation results for different subsamples of workers displaced from firm closures in 1980-2007. Standard errors in parenthesis. 
Figure 1: Former Coworker Networks

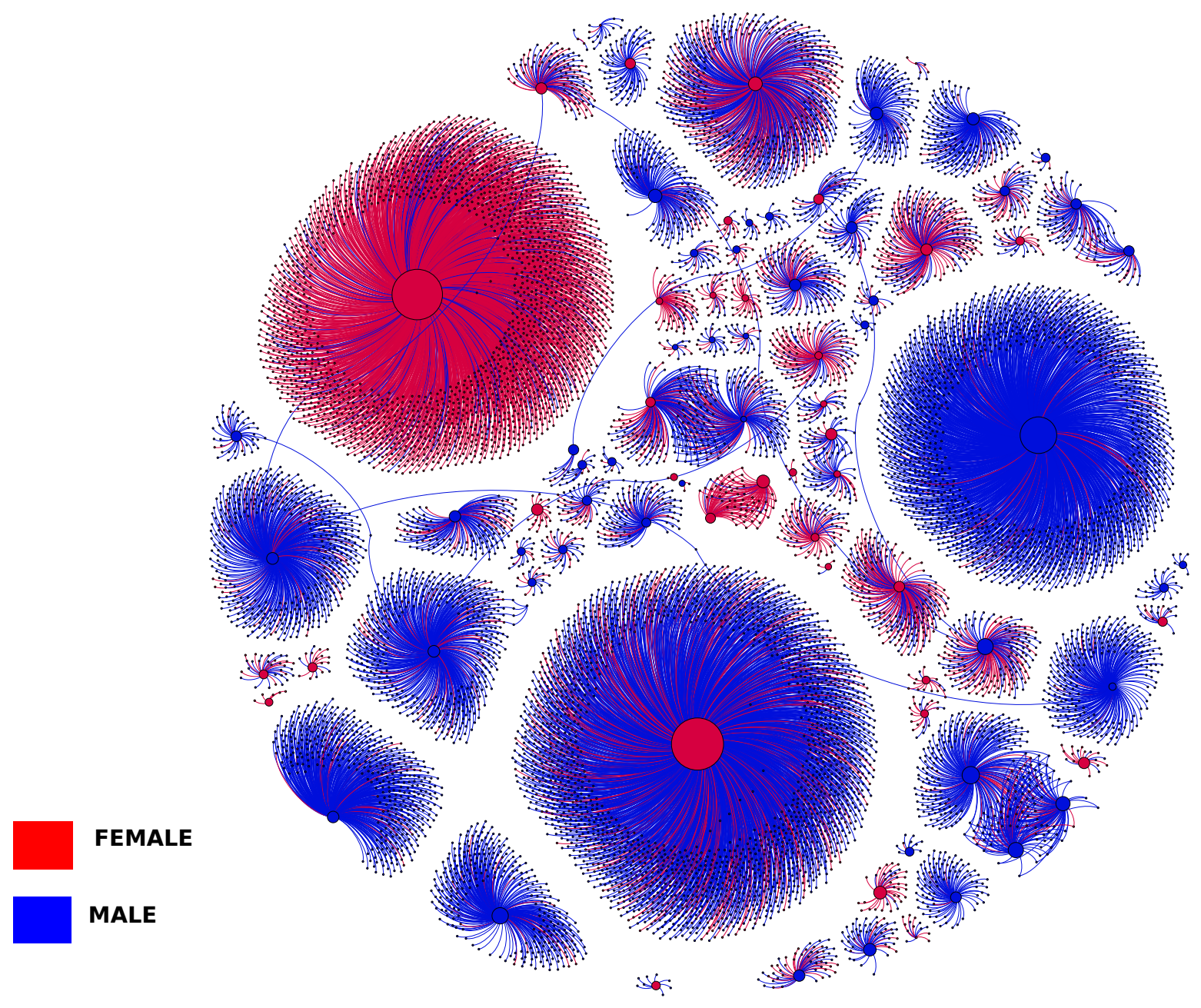

Note: The figure is based on a $1 \%$ random sample of 85 workers lost their jobs at closing firms in 2000. It illustrates the displaced workers (in the center) and their former coworkers as their connections. Blue (red) circles in the middle represents the male (female) job seekers while blue (red) connections around them are their male (female) contacts in their network. 
Figure 2: Firm Networks

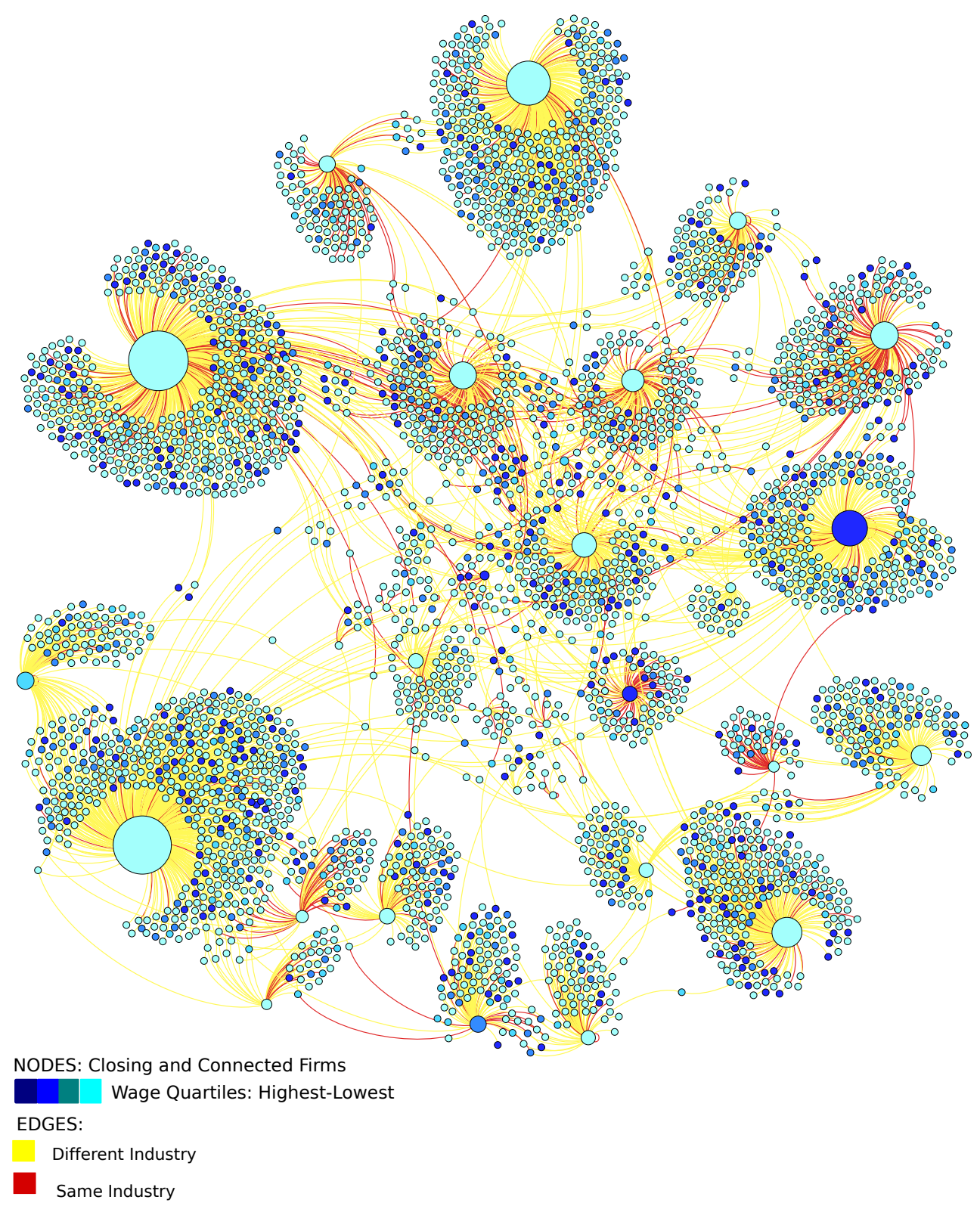

Note: The figure is based on is a random sample of 60 firms closing in the year 2000. At the center of each network is the closing firms, edges represent links to connected firms. The color of the edge represent industry connections: a red edge means that the pair of closing and connected firm are in the same industry, while a yellow edge represents for different industries. The nodes are colored by the wage quartiles of the firms, with a lighter blue color representing a lower quartile firm 
Figure 3: New Job Hazards by Network Employment Rate

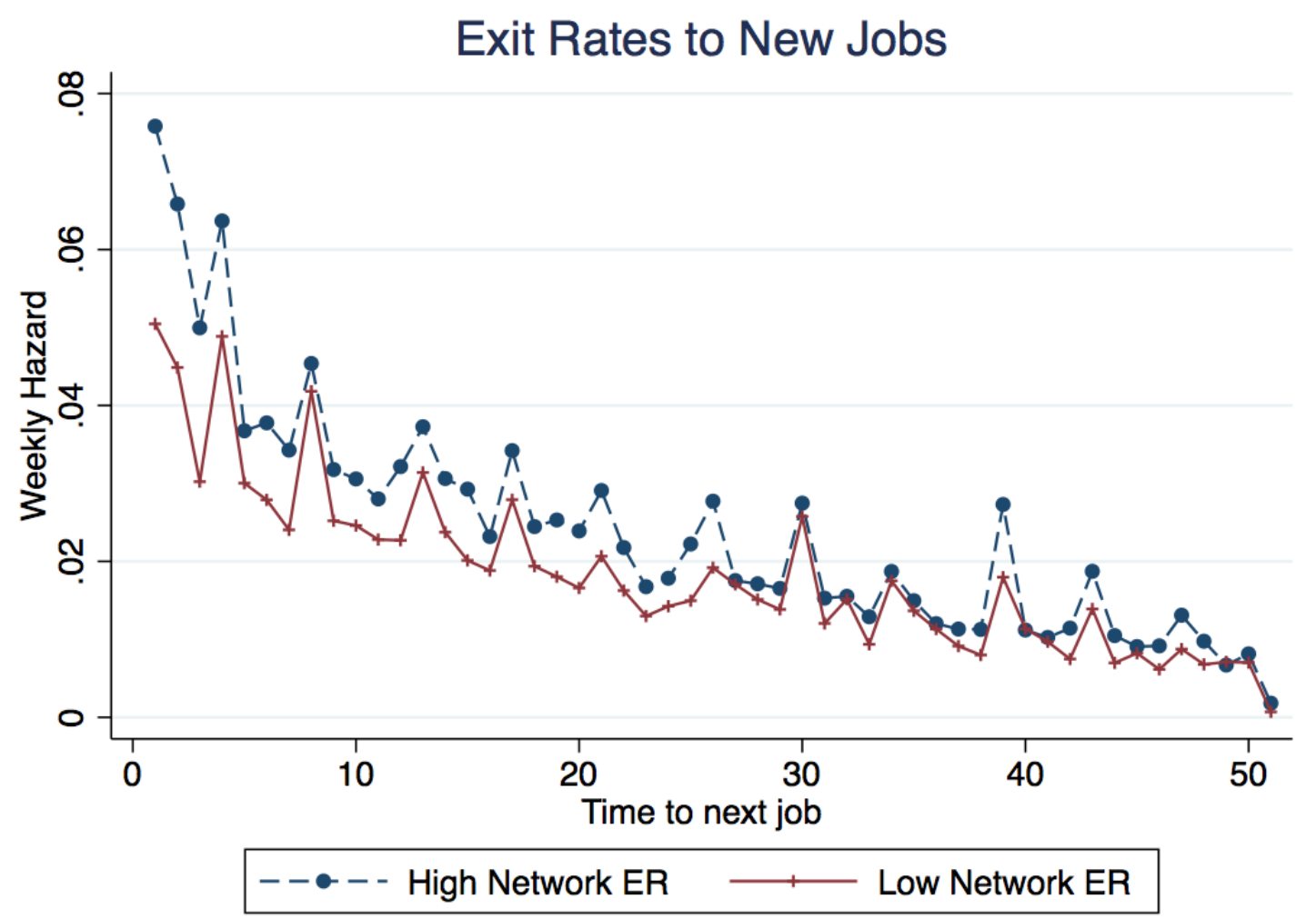

Note: The graph plots weekly hazard rates into new jobs over the first year after displacement for two subsamples: displaced workers with a share of employment former coworkers in the top quartile of the distribution, denoted as "high network employment rate", and displaced workers with a share of employment of former coworkers in the bottom quartile of the distribution, denoted as "low network employment rate". 